Paideusis

\title{
Subjects-in-Process/ on-Trial: The Construction of Teacher Subjects in an Early Field Experience Course
}

\section{Jacqueline Bach}

Volume 17, Number 1, 2008

URI: https://id.erudit.org/iderudit/1072463ar

DOI: https://doi.org/10.7202/1072463ar

See table of contents

Publisher(s)

Canadian Philosophy of Education Society

ISSN

0838-4517 (print)

1916-0348 (digital)

Explore this journal

Cite this article

Bach, J. (2008). Subjects-in-Process/ on-Trial: The Construction of Teacher Subjects in an Early Field Experience Course. Paideusis, 17(1), 3-12. https://doi.org/10.7202/1072463ar
Article abstract

Increased standardization of teacher education programs urges a reconsideration of how pre-service teacher identities are constructed/being constructed and evaluated. The purpose of my study was to examine the writings of pre-service teachers enrolled in an early field experiences course in order to identify moments in which they interacted, negotiated, and subverted the teacher-making process, which they officially enter during the semester they take this course. I approach this question from a philosophical viewpoint, and I use the theories of French post-structuralist, Julia Kristeva. My analysis of pre-service teachers enrolled in an early field experience course illustrates how their language disrupts the standardized language and expectations of a teacher education program.
This document is protected by copyright law. Use of the services of Erudit (including reproduction) is subject to its terms and conditions, which can be viewed online.

https://apropos.erudit.org/en/users/policy-on-use/ 


\title{
Subjects-in-Process/ on-Trial: The Construction of Teacher Subjects in an Early Field Experience Course
}

\author{
JACQUELINE BACH \\ Louisiana State University, USA
}

\begin{abstract}
Increased standardization of teacher education programs urges a reconsideration of how pre-service teacher identities are constructed/being constructed and evaluated. The purpose of my study was to examine the writings of pre-service teachers enrolled in an early field experiences course in order to identify moments in which they interacted, negotiated, and subverted the teacher-making process, which they officially enter during the semester they take this course. I approach this question from a philosophical viewpoint, and I use the theories of French post-structuralist, Julia Kristeva. My analysis of pre-service teachers enrolled in an early field experience course illustrates how their language dismpts the standardized language and expectations of a teacher education program.
\end{abstract}

\section{Introduction}

As teacher educators struggle to reconcile the demands placed upon them by the increasing call for accountability, they find themselves trying to integrate catch phrases and buzz words into their existing program philosophies (Moore \& Johnson, 2006). During meetings, faculty speak of the knowledge, skills, and dispositions their teacher candidates, a term which is now replacing pre-service teacher, ${ }^{1}$ must possess in order to become effective teachers. Yet, teacher education faculty are not the only ones who must adopt and learn this language-pre-service teachers are also expected to understand and use it themselves, often in writing, in order to convey their identities as future teachers. Pre-service teachers who negotiate this language in their writings may be able to alter those very expectations teacher educators and education programs have of them.

For pre-service teachers, constructing an identity is not just based on their previous experiences as students. Educational programs (here I speak on behalf of those in the United States), are shaped by federal, National Council for the Accreditation of Teacher Education (NCATE), state, university (Cochran-Smith, 1991; Lloyd, 2005), national organizations (Larson, 2005), district and school level rules and regulations (Geijsel \& Meijers, 2005) and teacher educators' agendas (R. Moore, 2003). Based on these standards, colleges of education determine what pre-service teachers should learn and

\footnotetext{
${ }^{1}$ Pre-service teacher in this context is a student who has not yet completed an internship.

Copyright 2008. The author, Jacqueline Bach, assigns to Paideusis the right of first publication and educational and non-profit institutions a non-exclusive license to use this document for personal use and in courses of instruction provided that the article is used in full and this copyright statement is reproduced. Any other usage is probibited without the express permission of the author.
} 
experience during their teacher education program. Caught at the intersection of personal and institutional expectations, pre-service teachers may feel as if they must only work within the parameters of this system in order to become licensed-or in my students' cases-to pass my course and be accepted into the college's teacher education program.

The purpose of this qualitative study, which relies on feminist post-structuralist discourse and a theoretical framework derived from French philosopher Julia Kristeva's notion of the subject-inprocess/on-trial, seeks to identify how pre-service teachers construct and reconstruct their identities during an early field experience course. ${ }^{2}$ From a Kristevian perspective, my students might be viewed as already negotiating the teacher-making process through the reappropriation of educational terminology, the contradiction of teaching philosophies, and the disruption of expectations. In this essay, after I briefly discuss Kristeva's subject-in-process/on-trial notion, I will focus on one way my participants' identities are formed/forming through the disruptions located in the various writings and presentations they completed during an early field experience course. I will then describe this concept, locate it within Kristeva's work, offer examples of it from the data, and highlight how this analysis illustrates the formed/forming identities of pre-service teachers.

\section{Julia Kristeva and the Subject-in-Process/on-Trial}

Researchers often conclude that it is important for pre-service teachers to form strong identities in order to avoid "unlearning" what they have gained from their education programs (Cochran-Smith, 2003; Toll, Nierstheimer, Lenski, \& Kollof, 2004). Studies also suggest that a strong sense of identity will help them negotiate the personal and professional aspects of their chosen career (Alsup, 2006; Atwell-Vasey, 1998). What these studies share is the perception that pre-service teachers must have the ability, the skill, to develop an identity which can "withstand" the pressures of the profession. These expectations trickle down to teacher education programs, like the one in this study, which expect preservice teachers to express a strong sense of what type of teacher they will be (knowledge, skills, and dispositions) or be able to negotiate this intersection(s) in their writings. What Kristeva can lend to ways of analyzing this stage of identity formation is a "new" way of understanding these moments in which pre-service teachers' writing is choppy, negative, questionable, contradictory, and unexpectedterms which researchers (Alsup, 2006; Anderson, Barksdale, \& Hite, 2005; Bickmore, Smagorinsky, \& O'Donnell-Allen, 2005; Goldstein \& Freedman, 2003) have attached to their participants' words. Preservice teachers might not be rejecting the language of their chosen profession; instead, they might be working through it to express their negotiations between what they have known to be true and what they are being asked to write and do.

Before I begin to discuss Kristeva's theory on the subject-in-process/on-trial, it might be beneficial to examine how her work detours from the work of one of her teachers-French poststructuralist Jacques Lacan. Lacan, keeping Freud in mind, proposed that, sometime between six and 18 months, infants enter what he calls the "mirror stage." During this stage, infants recognize themselves in the mirror. For the first time, they see themselves not through someone else's gaze-for example, through their mother's-but through their own. When they discover their own image, they must leave the maternal stage, represented by their mothers, in order to enter the paternal stage in which they seek to name their identities. Once they begin using the language of their father (words, syntactical rules) the maternal is repressed, and they cannot return to the stage before the mirror, to the stage before their mother's language.

This break, which Kristeva calls the "thetic phase," is a beginning of sorts (Atwell-Vasey, 1998). The Kristevian semiotic/symbolic binary sustains, according to Wang (2004), "the founding moment of

\footnotetext{
2 In this early field experience course, secondary education students spend 45 hours in schools, observing,
} assisting, and teaching and then spend an hour in group discussions on campus. 
identity upon separation" (p. 111). Now, when subjects desire to express some bodily drive, they must turn to the symbolic (language) in order to name their experiences. ${ }^{3}$ Kristeva, in a sense, renames Lacan's ideas of the paternal with symbolic and the maternal with semiotic. She explains that the symbolic represents the laws associated with the father, and in language those laws are syntactical order and grammatical standards. On the other hand, the semiotic represents the pulsations and rhythms located within language. Kristeva chooses the word "transverbal" rather than "nonverbal" to describe her meaning of the semiotic "which is not independent of language; it interferes with language and, under its domination, articulates other arrangements of meaning, which are not significations, but rhythmic, melodic articulations" (1997/2002, p. 259).

Kristeva posits that in the (Oedipal) self, the symbolic normally suppresses the semiotic (Wang, 2004). Without delving too far into the psychoanalytical theory that accompanies this explanation, this suppression might occur because a subject desires the unity that the symbolic offers. However, subjects can submit to the symbolic, and in a sense become trapped by it. When the semiotic does appear in the symbolic, other meanings are articulated and one's subjectivity undergoes dissolution. Kristeva $(1974 / 1984)$ names this process "le sujet-en-procès" which means both the subject-in-process and the subject-on-trial, for the term can be translated either way. In the subject-in-process/on-trial, the semiotic can challenge the "boundaries, laws, and constraints that it meets" (Kristeva, 1974/1984, p. 101) while the symbolic regulates the semiotic. When pre-service teachers deal with the tension between their semiotic drives and the symbolic boundaries, they can engage in a "creative meaningmaking process that upholds both structure and surprise" (p. 91). In this interpretation, colleges of education as well as other educational institutions represent the symbolic by deciding which words and which format their pre-service teachers must use to describe their experiences. These regulations make it possible for some of my participants to negotiate their identities by disrupting this process in their writing.

I agree with Weedon (1997) that researchers who believe subjects' identities are unstable and fluid find Kristeva's theories attractive. Furthermore, Kristeva's thoughts on desire remind us that preservice teachers, for the most part, want to find their identities as teachers. Perhaps, possibly unconsciously, they understand that in order to express themselves in the writings they complete as part of their programs, they will have to use someone else's language in addition to their own.

\section{Data Collection}

I collected the data for this study during the course of one semester from the students in my Field Experiences in the Secondary Schools course taught at a mid-sized, mid-western university in the United States. ${ }^{4}$ The course requires students to spend 45 hours in a secondary public school observing and participating in a cooperating teacher's classroom. There were 18 participants-16 female, 2 male-who were majoring in various disciplines of secondary education. (Mathematics, science, English/language arts, foreign languages, and social studies were all represented.) Sixteen were White, one was of Hispanic heritage, and one was of Asian heritage. Throughout the semester, students wrote eight essays, kept a field experience log in which they recorded what they observed in their schools, kept a dialogue journal, and presented a summary of their experiences in the field to their classmates. For this essay, which is taken from a larger study, I focused on their writings only, including the field experience log, the dialogue journal, and their essays.

\footnotetext{
${ }^{3}$ Kristeva gives the example of children attaching the onomatopoetic "woof-woof" to a dog as an example of how infants identify themselves through the similarities and differences of another person or object before they see the Other (themselves) in Lacan's mirror (Kristeva, 1974/1984, p. 43).

${ }_{4}^{4}$ This study was conducted at a university at which I previously taught.
} 


\section{Data Analysis}

These assignments served not only as the data for this study but also determined my students' grades for the course. I first read and evaluated these writings using the course's grading rubric. At the end of the semester, I reread each piece several times, noting spots in my students' writing which seemed awkward, incomplete, or out of place with the assignment. Inspired by feminist post-structural approaches, I began to reexamine those moments from a different point of view. A feminist poststructural approach to discourse analysis (Weedon, 1997) focuses attention on those places in subjects' writing and (re)considers possible interpretations of those moments. Feminist post-structuralist approaches can begin with the gaps and contradictions located within "discursive representations" and have the ability to change the nature of the questions asked about a text (Marshall, 2004, p. 268). In other words, those instances in their students' writings that teacher educators may dismiss as sloppy or careless work might be reinterpreted as examples of pre-service teachers engaging with an institution's expectations of them.

My analysis was also influenced by Atwell-Vasey's (1998) study of three autobiographical narratives written by English/language arts teachers on their personal and school experiences with reading and the teaching of literature. Atwell-Vasey employs psychoanalytical theory, in particular Kristeva's, to analyze her participants' writings. She notes sections of her participants' writing which are choppy, rhythmic, and repetitious and connects those instances into a discussion on how their personal reading habits work their way into their teaching practices.

In my data analysis, I identified moments in my students' writings when their language and thoughts intersected with the context and language of the teacher-making process in which they were immersed. After rereading their writings with the college of education's, NCATE's, and my own instructions in mind, I separated textual excerpts into groups based on similarities in types of writing (for example, those who directly addressed the reader about the parameters of the assignments went into one pile; those who misused terms went into another). I then turned to Kristeva's work to locate names/categories for the themes I found in the coding of my students' writings and decided upon contradictions, reappropriations, and disruptions. In this essay, I will focus on disruptions, as they occurred most frequently in my students' work.

\section{Disruptions}

For Kristeva, the semiotic disrupts the linear order of texts, whether it is the syntactical or structural aspects of language. While some disruptions in my students' writing are possibly a result of poor proofreading or editing, there are moments in which they clearly disrupt the expectations of the assignment. Sometimes, they try to convey some aspect of their experience that does not fit the assignment's boundaries. Disruptions are one way the semiotic emerges in language as it is a "traumatic, unexpected, even violent" (Lechte \& Zournazi, 2004, p. 217) way for subjects to negotiate the boundaries put into place by the symbolic, in this case, the parameters of the assignment. When my students' writings disrupt the symbolic, they tend to resemble someone who is no longer willing to "go along" with the rules but needs a way of expressing how he or she "really" feels about something. They reach out to the reader, alerting her that this essay might be a total farce or a product that itself will continue to be engaged in a process.

\section{Disrupting the Boundaries}

These statements that stand out because they are not in line with an assignment's parameters seem to be associated with participants' growing understanding of the "realities" of the teaching profession. 
They then become unable to fit those understandings into the narrowness of the course's essays' prompts which might ask them to focus on one aspect of teaching or the profession. Students "play" with the language and with the tasks they must complete as part of this course. For example, a foreign languages pre-service teacher, Nina, questions the very notion of what it means to observe during the early field experience course. In the following excerpt from her teaching philosophy statement, Nina realizes that although she has been led to believe the purpose of a field experience class is to sit at the back of the classroom and observe, she has found that involving herself with the students and the lesson is more rewarding. She writes:

\footnotetext{
I know that this is my last assignment and paper for this class ... Before this course, I believed that the main objective when going into both my elementary and secondary school placements was to observe [her emphasis] the teacher and their classes. This lesson is just another example of how I enjoyed getting to be a part of Mrs. Edison's class. And honestly, isn't that what this class, and more specifically, this assignment, is all about?
}

Nina openly addresses the boundaries of the task by adding her own impressions of the purpose of the course and the assignment. In this way, she is not only negotiating with the writing assignment but also with the course and with me, the instructor.

Perhaps the best example of my students' disrupting the structural aspects of my assignments comes from their field experience logs. At the beginning of the semester, I provided my students with a guide for preparing a field experience log and the minimum number of entries they were to complete during their 45 hours of observations. Karen's field log serves as an excellent demonstration of how participants may contradict these guidelines in order to reconcile themselves with the structure I provided them. The four parts to an entry are 1) Heading, 2) Sequence of events, 3) Elaboration of one or two episodes, and 4) Analysis of one of these episodes. In Karen's journal, she stapled the instruction sheet I passed detailing the four parts to a log entry to the inside front cover of her notebook. On the first page of the notebook, Karen listed the four parts of an entry again with notes for herself on the type of content that was to be included in each section. However, the rest of her log does not follow my parameters. Here is a sample entry from her log. (All of her entries are handwritten and I have recreated the format she uses.)

2 |24|06

\section{$\underline{\text { AP English 6 }} \underline{\text { th }}$ Period}

One of the students puts a saying

of the day on the board

Fridays are quiz day

Some come in late-not sure why they are late.

They are a funny bunch.

Nice feeling. Comfortable.

Kids are working on Cross word puzzles

Very casual

Joke a lot—witty

The students made crossword puzzles

And then they traded and completed it. 
While some of her entries contain more detailed reflections, they all lack numbered lists or the four distinct sections recommended in the instructions. Furthermore, she sometimes marks certain lines with asterisks; sometimes the date is recorded in the upper right-hand corner. Many of them, like this entry, have the "look" of poetry-fragments, stanzas, and references to the emotions, images, and atmosphere of the classroom. Karen's entries do follow the sequence of the lessons she observes; however, those categories-heading, sequence, elaboration, analysis-do not allow room for the semiotic, which Karen tries to capture in her log. She is unable to capture the "Nice feeling" and "Comfortable" atmosphere within the analysis of a particular episode. The result of her wanting to comment on the importance of the classroom's vibe disrupts the linear order of the field log's format.

\section{Distuptive Silence}

Another disruption of the symbolic/structure that occurs in my students' writing is what they decide not to put into language. These moments of silence emerge in several ways in my participants' essays. For example, students may interrupt the traditional syntactical or structural flow of an essay when they fail to elaborate on statements they make or connect these statements to the rest of their work. These silent moments might indicate a time when the semiotic and the symbolic cannot function together to express a subject's experience. In other words, because there exists an expectation that writers would elaborate on some statements, failure to do so results in an awkward moment for the reader.

The most common example of how my participants employ silence occurs when they do not comment on certain statements they make about their experiences observing their cooperating teachers. For example, in an essay on assessment and evaluation which asks students to comment on their cooperating teacher's authentic/inauthentic assessments, Krissy slips in the statement "I think her [the cooperating teacher's] assessments are very authentic," without explaining what she means:

Lab time is a reward for the students. So, she [Krissy's cooperating teacher] had to modify her lesson plan according to what happened during the day. I think her daily assessments are very authentic. She had been teacher for quite some time and is an excellent teacher.

The reason behind Krissy's lack of further elaboration and other examples of this type of disruptive silence remains ambiguous. Krissy simply chooses not to discuss her use of the term "authentic"; perhaps she assumes her reader already knows what it means or maybe she does not. There is a distinct choppiness to this paragraph and perhaps Krissy is merely answering the questions in the order that they are presented in the assignment's directions. Or perhaps she does not fully understand the term but does understand the importance of including it in her essay to meet the parameters of the assignment.

Nina employs a similar type of silencing in her writings. She, too, disrupts the otherwise smooth structure in her essay on her cooperating teacher's classroom management strategies when she does not elaborate on a statement she makes about her cooperating teacher's school. In an essay on her teacher's discipline practices, she notes:

In my opinion, there seems to be a complex hierarchy of discipline at this school. Here are assistant vice-principals, vice-principals, assistant principals . . I cannot keep track of them all. However, those men seem to be who the teachers call if there is ever a problem they cannot handle.

Nina does not elaborate any further. Is her remark directed toward the overabundance of male administrators at the school she observes? Is she commenting on the females turning toward the males as a last resort? Oliver (1993), working with Kristeva's theories, notes that "There is always something 
that cannot be said and that is why we keep talking" (p. 97). Nina keeps writing about discipline without revealing her feelings about her observation.

Secondly, and more difficult to spot in polished writings, are moments of self-censorship. In this type of silencing, a subject attempts to "fit" the semiotic into the symbolic. For example, in another field experience log entry, Sarah may be "silencing" herself from seeming as if she knows what it must be like to teach world history. In a sentence in which she muses on the difficulty of teaching world history, Sarah crosses out one verb and replaces it with another word. However, it is still possible to read the original word. Sarah reflects "To me, World History is seems to be [sic] one of the most difficult subjects to [sic] teach." Sarah seems to be cautious about making assumptions about a profession she hasn't actually entered yet, but what is interesting is for whom she is making her revisions and under what conditions. When she crosses out the word "ever," for example, is she correcting a split infinitive, and if so, why would she revise a piece of writing that is informal and not evaluated by a rubric? Why does she feel the need to replace "is" with the more tentative "seems to be"?

The silence which emerges in my students' writings serves to comment on their cooperating teachers' habits. Their silences might be signs of disapproval or disagreement with certain practices. I'm not sure why my students did not feel comfortable elaborating on some of these sentiments. It would be very rare that anyone either than I or their fellow classmates would be reading their work. Wang (2004) contends that "usually the site of silence is where articulation can take a form of social critique" (p. 110). Perhaps, as the instructor of this course, their silence was directed at me, in the hopes that I could initiate some changes in the field experience coursework or out of a fear of me as an authority figure; perhaps their silence reflected a cultural or personal reluctance to critique someone with more experience in teaching; perhaps their silence reflected a lack of self-confidence. If students are able, as Kelly is, to disrupt the symbolic then that might be a way for them to use the semiotic to bring about productive changes in the symbolic.

\section{Disrupting the assignments}

Another assignment in which the semiotic disrupts the symbolic is the professional goals essay. In this essay, students were asked to predict what type of job they would have in five years, including the grade they would teach, where they would teach, and what they would teach. Rebecca disrupts the assumptions inherent in writing a goals statement at the inception of one's entry into a secondary education program: "In fact, by the time I finish this paper, I may not agree with certain things that I stated." Rebecca does not openly refute the assignment; instead she prepares the reader for any contradictions she might make in the course of her essay. Likewise in an essay in which students must predict where they will be teaching in five years, Joy writes "It is nearly impossible for me to predict my teaching environment because I do not know in what kind of environment I will be teaching."

The second part to this essay assignment asked students to identify three to five goals for their future careers and how they would achieve those goals. Ginger speaks to the problems of an assignment in which she has to state her professional goals before she has even finished the teacher education program: "When I began to attempt to determine what I considered to be my professional goals, I realized something very important: I do not plan." She again tries to account for her nature not to plan, and to perhaps be rather whimsical: "However, as I stated above, the "plans" are just speculative, and who knows if in a month I will change my mind completely and want to teach Spanish in Kansas." In spite of her continual assertions that she does not plan, Ginger makes clear her one goal: "In conclusion, my lone professional goal for the future is simple: I want to be the best teacher I can, no matter who is sitting in my classroom or where I am." Ginger completes the assignment and follows the parameters, but she feels the need to maintain her views of goal-setting. In fact, not planning seems to play an important role in the way she conducts her life. She does admit to having a goal; however, 
she recognizes the possibility that her goals will inevitably change as she continues in the process of becoming a teacher.

\section{Conclusion}

One message teacher educators may take from Kristeva's notion of the subject-in-process/on-trial is an understanding of how pre-service teachers are negotiating the teacher-making process and how that negotiation may surface in their writings. Teacher educators might reconsider then the awkward, contradictory, or disruptive moments in their students' writing as something other than careless errors, questionable statements, or inexperience. Instead, these moments arise mainly because there is a structure in place for pre-service teachers to negotiate. As Oliver (1993) points out, "Without the symbolic function within the symbolic order, the semiotic could never be transformed into a practice, and certainly not a revolutionary practice" (p. 97). When discussing Kristeva's work, Letche and Margoroni (2004) challenge that "Ethical practice, then, amounts to using the semiotic to bring about changes in the symbolic order itself" (p. 108). What then is the teacher educator's responsibility to the writings of their pre-service teachers? Kristeva, I believe, would suggest that it is not the teacher educator's duty to "pass judgment" on students based on their writings. Instead, she might encourage teacher educators to revisit these moments of disruption, contradiction, and reappropriation with their students in order to resist the notion that this is the only way to use the language of the teaching profession to talk about their identities.

For Kristeva (1997/2002), the subject "restarts" in order to "question value systems," "make judgments" and "question things from the place of another subject" (p. 137). It therefore may be important for teacher educators, as well as pre-service teachers, to understand how our identities are influenced by all of the parties involved in the teacher-making process and that "eternally contradicting," "forever reconciling," and "testing the very possibility of unitary meaning" (Kristeva, $1997 / 2002$, p. 10) is a way of rereading comments such as Kagan's (1992) conclusions on beginning teachers' identities: "Novices who do not possess strong images of self as teacher when they first enter the classroom may be doomed to flounder. . . The image of self as teacher must also be adapted for the realities of teaching" (p. 163). Although Kagan's conclusions do not acknowledge the potential of "inappropriate" images in subverting the traditional notions of "teacher," I do not believe that these two directions are contradictory.

The subject-in-process/on-trial is central to Kristeva's culture of revolt, and the notion of "restarting" is a productive one to consider in pre-service teacher education. If new teachers begin to move to the status quo, perhaps engaging in tasks that "restart" their identities will recharge their teaching. In accordance with Geijsel and Meijer's (2005) definition of identity as "the ever-changing configuration of interpretations that individuals attach to themselves, as related to the activities that they participate in" (p. 423), many attempts to prevent teachers from changing their teaching philosophies are probably futile and unimportant. Instead, these changes are inevitable, and if teachers can recognize their changes in philosophy, then revolt becomes possible and productive. For scholars like Britzman (2003), narrative, "or making significance from the accidental quality of life events" is one way to engage in a practice that "resides in revolt" (p. 23).

Although this practice might not have a place in many of today's teacher education programs, teacher educators, I would argue, have a duty to include pre-service teachers in this type of conversation. My findings suggest that returning to students' writings with them is a good place to start. When students consistently "misuse" a term, repeat a story, or contradict themselves, there may be a reason behind it other than carelessness or immaturity. Teacher educators who undergo a rereading of their students' writings looking for these moments, as I did, might find the importance of these examples in the forming/formation of their students' identities as teachers. That change would mean that teacher educators must become subjects-in-process/on-trial in regards to their own practices. 


\section{References}

Alsup, J. (2006). Teacher identity discourses: Negotiating personal and professional spaces. Mahwah, NJ: NCTELEA.

Anderson, N. A., Barksdale, M. A., \& Hite, C. (2005). Preservice teachers' observations of cooperating teachers and peers while participating in an early field experience. Teacher Education Quarterly, 32(4).

Atwell-Vasey, W. (1998). Nourishing words: bridging private reading and public teaching. Albany, NY: State University of New York Press.

Bickmore, S., Smagorinsky, P., \& O’Donnell-Allen, C. (2005). Tensions between traditions: The role of contexts in learning to teach. English Education, 38(1), 23-52.

Britzman, D. (2003). Practice makes practice: A critical study of learning to teach (Revised edition ed.). Albany, NY: State University of New York Press.

Cochran-Smith, M. (1991). Learning to teach against the grain. Harvard Educational Review, 62(3), 279310.

Cochran-Smith, M. (2003). Learning and unlearning: The education of teacher educators. Teaching and Teacher Education, 19, 5-28.

Geijsel, F., \& Meijers, F. (2005). Identity learning and educational change. Educational Studies, 31(4), 419430.

Goldstein, L. S., \& Freedman, D. (2003). Challenges enacting caring teacher education. Journal of Teacher Education, 54(5).

Kagan, D. (1992). Professional growth among preservice and beginning teachers. Review of Educational Research, 62(2), 129-169.

Kristeva, J. (1974/1984). Revolution in poetic language (M. Waller, Trans.). New York: Columbia University Press.

Kristeva, J. (1997/2002). Intimate revolt: The powers and limits of psychoanalysis (J. Herman, Trans. Vol. 2). New York: Columbia University Press.

Larson, A. (2005). Preservice teachers' field experience surprises: Somethings never change. Physical Educator, 62(3), 154-163.

Lechte, J., \& Margaroni, M. (Eds.). (2004). Julia Kristeva: Live theory. London: Continuum.

Lechte, J., \& Zournazi, M. (2004). The Kristeva critical reader. Edinburgh, Scotland: Edinburgh University Press.

Lloyd, S. (2005). Examining a framework of dialogue emails and inquiry into practice to scaffold reflective practice in preservice teachers during their early field experiences. Unpublished Dissertation, University of South Florida.

Marshall, E. (2004). Stripping the wolf: Rethinking representations of gender in children's literature. Reading Research Quarterly, 39(3), 256-270.

Moore, M. T., \& Johnson, T. S. (2006). The editorial we: Discussing teaching concepts. English Education, 38(3).

Moore, R. (2003). Reexamining the field experiences of preservice teachers. Journal of Teacher Education, 54(1), 31-42.

Oliver, K. (1993). Reading Kristeva: Unraveling the double-bind. Bloomington, ID: Indiana University Press.

Toll, C., Nierstheimer, S., Lenski, S., \& Kollof, P. (2004). Washing our students clean: Internal conflicts in response to preservice teachers' beliefs and practices. Journal of Teacher Education, 55(2), 164176.

Wang, H. (2004). The call from the stranger on a journey home: Curriculum in a third space. New York: Peter Lang.

Weedon, C. (1997). Feminist practice \& poststructuralist theory (2nd ed.). Oxford: Blackwell. 


\section{About the Author}

Jacqueline Bach is an Assistant Professor of English Education and Curriculum Theory in the Department of Educational Theory, Policy and Practice at Louisiana State University. Her areas of interest include pre-service teacher identity, young adult literature, and popular culture and pedagogy. She continues to examine pre-service teachers' field experience journals; however, her research agenda now includes whatever books her four-year-old son, Emery, wants to read (Thomas the Tank Engine, at the moment). Her email address is jbach@1su.edu 